\section{Spinal subdural \\ haematoma as a com- plication of immediate epidural blood patch}

Ismail H. Tekkök MD, David A. Carter MD PhD, Ray Brinker MD*
Purpose: The authors report a case of a patient who developed spinal subdural haematoma after a series of epidural blood patches to alert anaesthetists to this rare complication. Clinical Features: The patient was a 35-yr-old woman without coagulopathy and was initially treated elsewhere for chronic pain by repetitive epidural phenol injections. When the dura was inadvertently punctured during subsequent attempts to inject phenol, immediate epidural blood patch was performed to treat or prevent headache. The patient developed cauda equina syndrome after six epidural blood patches. The clinical diagnosis was confirmed by magnetic resonance imaging and the intradural haematoma was evacuated surgically. The patient made a complete recovery.

Conclusions: Epidural blood patch is not without complications. Transient backache and/or radiculopathy may occur in up to one-third of patients receiving a blood patch. If signs and symptoms continue or worsen, a spinal subarachnoid and/or subdural haematoma should be suspected and neurosurgical opinion sought. The technique used to identify the epidural space is important in preventing subdural injection of blood. The needle should be withdrawn after dural puncture and the epidural space identified at a different level. Blood patches may carry a higher risk of serious complications after multiple epidural phenol injections because of fibrosis and obliteration of the epidural space. Magnetic resonance scans reliably demonstrate the extent of the pathology. If diagnosed

\section{Key words}

ANAESTHETIC TECHNIQUES: epidural;

COMPLICATIONS: haematoma, subdural, blood patch,

headache;

PAIN: chronic.

From the Departments of Neurological Surgery and

Radiology*, Medical College of Ohio, Toledo, OH, USA.

Address correspondence to: Dr. Ismail H. Tekkök,

Children's Hospital of Eastern Ontario, Division of

Neurological Surgery, 401 Smyth Road, Ottawa, Ontario

K1H 8L1 Canada.

Phone: (613) 737-2316. Fax: (613) 738-4228.

Accepted for publication 12th November, 1995. and treated before irreversible changes occur, spinal intradural haematoma can result in complete recovery.

Objectif: Décrire un cas d'hématome rachidien sous-dural après des injections péridurales répétées de sang autologue (" blood patch ») et faire part à l'anesthésiste de la gravité de cette complication rare.

Caractéristiques cliniques: Il s'agissait d'une femme de 35 ans sans coagulopathie et qui avait été initialement traitée ailleurs pour une douleur chronique avec des injections épidurales répétées de phénol. Lorsque la dure-mère a été perforée accidentellement au cours d'une tentative d'injection de phénol, un "blood patch "épidural a été immédiatment réalisé pour le traitement ou la prévention de la céphalée. Un syndrome de la queue de cheval est apparu après six "blood patch " épiduraux. Le diagnostic a été confirmé par imagerie par résonance magnétique et l'hématome évacué chirurgicalement. La patiente a récupéré complètement.

Conclusions: Le «blood patch 》 n'est pas exempt de complications. Une lombalgie transitoire avec ou sans radiculopathie peut survenir chez le tiers des patients. Si les signes et symptôme continuent ou s'aggravent, un hématome sousarachnoüdien ou épidural devrait être suspecté et un consultation neurochirurgicale prescrite. La technique servant à identifier l'espace épidural est importante pour prévenir l'injection sous-durale de sang. L'aiguille devrait être retirée après une ponction de la dure-mère et un nouveau niveau identifié dans l'espace épidural. Le blood patch peut comporter un risque de complications graves plus important après des injections répétées de phénol à cause de la fibrose et l'oblitération de l'espace épidural. La résonance magnétique illustre fidèlement l'étendue de la pathologie. S'il est diagnos. tiqué et traité avant l'apparition de lésions irréversibles, l'hématome rachidien intradural ne devrait pas laisser laisser de séquelles.

In 1960, Gormley described the technique of injecting autologous unclotted blood into the epidural space near a dural puncture hole for the treatment of post-dural puncture headaches, the so called "epidural blood patch" (EBP). ${ }^{1}$ The literature since then suggests that the tech- 
TABLE Summary of the procedures (PDPH = postdural puncture headache)

\begin{tabular}{rllllll}
\hline Day & Level & $\begin{array}{l}\text { Planned } \\
\text { procedure }\end{array}$ & $\begin{array}{l}\text { Procedure } \\
\text { complication }\end{array}$ & $\begin{array}{l}\text { Procedure } \\
\text { performed }\end{array}$ & $\begin{array}{l}\text { Amount } \\
\text { injected }\end{array}$ & Outcome \\
\hline 1 & $\mathrm{~T}_{6-8}$ & Phenol neurolysis & None & Phenol neurolysis & $?$ & Temporary relief of abdominal pain \\
8 & $\mathrm{~T}_{6-8}$ & Phenol neurolysis & None & Phenol neurolysis & $?$ & Temporary relief of abdominal pain \\
25 & $\mathrm{~T}_{10-11}$ & Phenol neurolysis & Wet tap & Immediate EBP & $10 \mathrm{ml}$ & Partial relief of PDPH \\
30 & $\mathrm{~T}_{10-11}$ & Phenol neurolysis & Wet tap & Immediate EBP & $18 \mathrm{ml}$ & Transient backpain \\
32 & $\mathrm{~T}_{11-12}$ & EBP & - & EBP & $18 \mathrm{ml}$ & PDPH resolved \\
46 & $\mathrm{~T}_{12}-\mathrm{L}_{1}$ & Phenol neurolysis & Wet tap & Immediate EBP & $12 \mathrm{ml}$ & Partial relief of PDPH \\
47 & $\mathrm{~T}_{12}-\mathrm{L}_{1}$ & EBP & - & EBP & $18 \mathrm{ml}$ & Persistent backpain \\
61 & $\mathrm{~T}_{12}-\mathrm{L}_{1}$ & EBP & - & EBP & Cauda equina syndrome & ml \\
\hline
\end{tabular}

nique is both safe and very effective for the treatment or prevention of headache after dural puncture..$^{2-5}$

We recently diagnosed and treated a patient with a serious complication of the EBP technique. A spinal subdural haematoma occurred after six EBPs and this was apparently related to inadvertent dural punctures and subsequent injection of blood into the subdural space. We present this uncommon complication and highlight the potential spinal complications of EBP.

\section{Case history}

The patient was a 35-yr-old woman who had a ten-year history of abdominal and pelvic pain related to several abdominal operations. She had had coeliac axis blocks with phenol which had been successful on one occasion but not on others. She had been taking methadone on a regular basis but towards the end of 1994 even doses of $130 \mathrm{mg}$ every six hours were not effective.

The anaesthetist proceeded to epidural neurolytic injections using phenol. Two technically successful injections at $T_{6-8}$ levels were made. Although there was early relief of pain after the first injection, the pain recurred after $48 \mathrm{hr}$. A second injection was performed one week later. The patient was then discharged relatively pain free needing only mild analgesics.

When she returned two weeks later with pain, the anaesthetist attempted to inject more phenol epidurally. With the patient on her side, using the loss of resistance to air technique with an $18 \mathrm{G}$ Tuohy needle at $\mathrm{T}_{10}-\mathrm{T}_{11}$, the dura was inadvertently punctured and produced slightly bloody cerebrospinal fluid (CSF). Almost immediately the patient complained of the worst headache of her life, mainly in the frontal regions bilaterally. With the needle still in place, the anaesthetist promptly performed an EBP. After first withdrawing the needle until CSF could not be aspirated, $10 \mathrm{ml}$ of blood were injected into the epidural space. The patient was then placed in $10^{\circ}$ Trendelenburg for $20 \mathrm{~min}$ and horizontal for another $20 \mathrm{~min}$. The headaches were only partially relieved.
Subsequently, two attempts to place a Tuohy needle into the thoracolumbar epidural space for phenol injection both resulted in dural puncture for which the anaesthetist again considered immediate EBP using the above technique. Both immediate patches were reinforced by another EBP in a day or two (Table). During and after the fifth EBP, the patient started to experience severe and persistent backpain. The final EBP was performed three days before transfer to our institution and produced excruciating pain down her right leg with numbness in her left leg. First, the pain was down to the right knee but quickly extended to the toes. After two days she was unable to void urine and the bladder was catheterized.

On neurological evaluation, the power in her legs was decreased (4/5) bilaterally with saddle type sensory impairment. The deep tendon reflexes in both legs were hypoactive. The straight leg raising test was positive at $15^{\circ}$ bilaterally. The spinal axis from the midthoracic to low lumbar area was tender to touch. The clinical diagnosis was of cauda equina compression. Magnetic resonance imaging (MRI) demonstrated heterogenous hyperintensity within the dural sac at $L_{2}$ and $L_{3}$ levels (Figure A, B). There was no evidence of infection. Platelet count, prothrombin and partial thromboplastin times were all within normal range.

Next morning, a laminectomy was performed at $\mathrm{L}_{2}$ and $L_{3}$ levels which revealed no blood, pus or any sign of infection in the epidural space. The dural sac was tense and non-pulsatile with purplish discoloration. When the dura was opened, an admixture of brown organized and red freshly clotted haematoma extruded under pressure and was removed. She was discharged from hospital on the eighth day and neurological examination was normal at seven months.

\section{Discussion}

After EBP, transient symptoms such as backache, neck stiffness and radicular discomfort have occasionally been reported but these symptoms almost never led to 

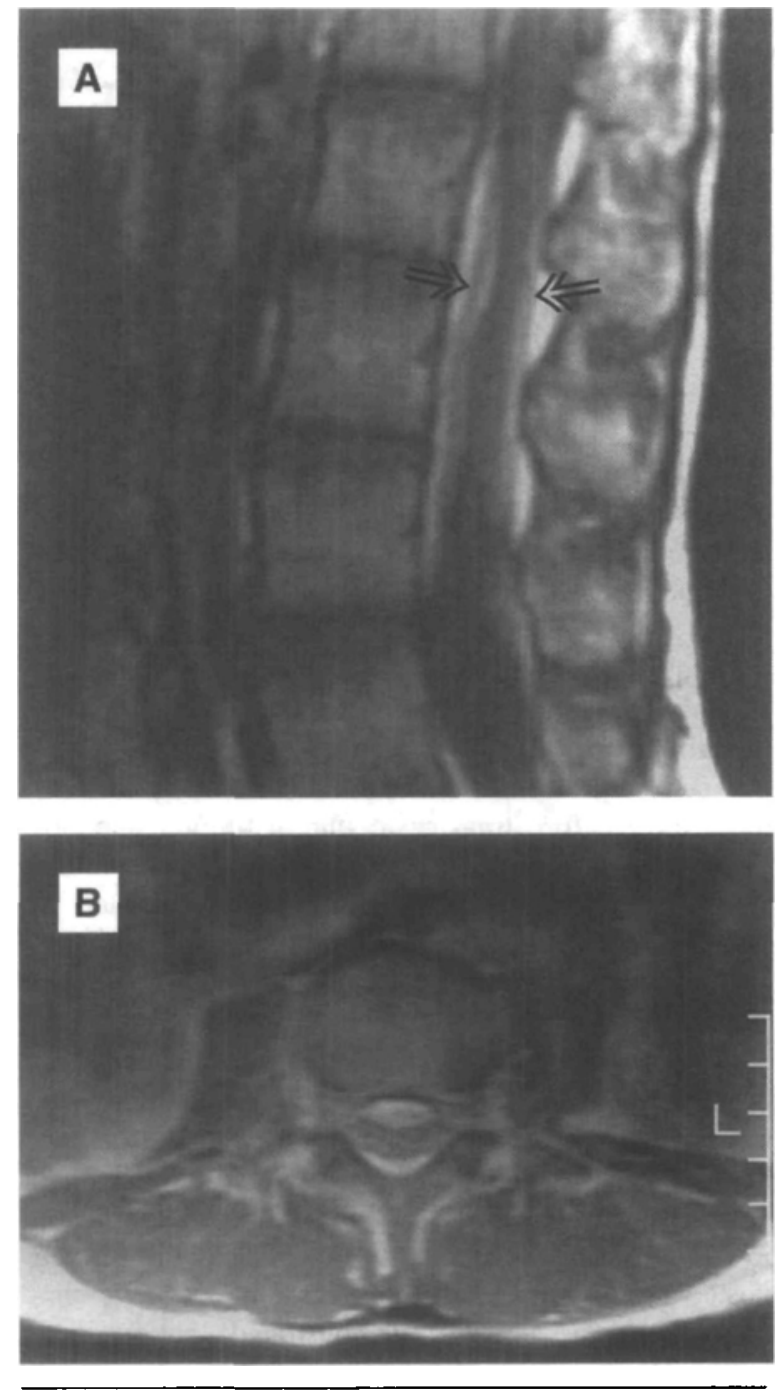

FIGURE (A) $\mathrm{T}_{1}$-weighted sagittal MRI demonstrating anterior and posterior slightly hyperdense columns at levels $\mathrm{L}_{2}-\mathrm{L}_{3}$. The marked hyperintensity of the epidural fat clearly demarcate the intradural haematoma. (B) Proton density axial MRI through $\mathrm{L}_{3}$ lamina depicting the compression of the cauda equina elements both anterior and posteriorly.

persisting neurological deficits. ${ }^{6-8}$ Ostheimer et al. $^{4}$ mentioned that of $15(8 \%)$ patients in a series of 185 , complained of transient backache or stiff back and paraesthesiae in the legs within minutes of the patch, but in only four (2\%) did backache persist for 24-30 hr. The incidence reported by Abouleish et al..$^{5}$ was much higher but the time sequence was similar. In a series of 118 patients, they reported that $35 \%$ complained of backache for up to $48 \mathrm{hr}$ after EBP but again these symptoms subsequently cleared. No radiological study was undertaken in these series and, thus, the cause of the symptoms was speculative. In a recent study, utilizing MRI technology, Beards et al. ${ }^{9}$ were able to demonstrate in transitionary symptomatic patients that EBP injection caused an initial compression over the dural sac and the nerve roots. However, clot resolution as early as seven hours was demonstrated with a final thick layer of mature clot over the dorsal aspect of the dural sac.

From a safety standpoint, identification of the epidural space is the most critical part of an EBP placement. Blood does not have a pharmacologic effect such as that of local anaesthetics to indicate its presence in different compartments, ${ }^{10}$ but it may have a volume effect. If an immediate EBP is to be undertaken in the event of an inadvertent dural puncture, it is much safer to perform the EBP through a separate skin puncture, either above or below the present puncture. It is potentially dangerous to withdraw the needle from the subarachnoid space and to inject the blood at the point where the flow of CSF stops since blood then can easily be injected into the subdural space and/or into the subarachnoid space even though the flow of CSF has stopped.

Only one similar case has been reported previously. Reynolds et al. ${ }^{11}$ reported a 25-yr-old woman who developed lower extremity "pulling" sensations after the sixth EBP, all done for her persistent dural puncture headaches. Neurological examination was normal but no radiological study was done. Taken for exploratory lumbar laminectomy with a presumptive diagnosis of persistent CSF leak, an unexpected subdural haematoma at $\mathrm{L}_{1}-\mathrm{L}_{3}$ levels was found and removed. The technique of withdrawing the needle until CSF flow stopped to identify the epidural space before the patch was the common event in that and our case. We believe that the previous epidural phenol injections in our case may also have contributed to unusually frequent inadvertent dural punctures since epidurally injected phenol causes local tissue necrosis (in this case epidural fat) and subsequent fibrosis leading to obliteration of the epidural space at lower thoracic levels. ${ }^{12}$

Spinal subdural haematoma with resulting cauda equina compression in patients without coagulopathy has rarely been reported in the anaesthesia literature. ${ }^{13}$ In such patients without coagulopathy, such a spinal haematoma may be difficult to diagnose clinically since the syndrome of back pain and/or myelopathy can initially be vague or mild. Unfortunately, once the full picture of neurological impairment develops, it is usually too late for any treatment. Therefore, even mild neurological findings should be interpreted with a high index of suspicion. In fact, any patient experiencing persistent and progressive backpain and/or neurological symptoms 
after an EBP deserves thorough neurological examination(s) and/or a neurosurgical consultation. If the findings suggest neurological impairment, imaging of the spine will be necessary.

MRI, being very sensitive to the paramagnetic effect of iron within the haemoglobin molecule, should be the diagnostic procedure. ${ }^{14}$ As underlined previously, an acute spinal haematoma will appear as isointense on $\mathrm{T}_{1^{-}}$ and hyperintense on $T_{2}$-weighted images, while subacute haematomas will appear hyperintense on both $T_{1}$ and $\mathrm{T}_{2}$ weighted images. ${ }^{14}$ Although the early MRI appearance of a successful EBP may closely resemble an acute haematoma, the fact that this clears by the 18th hour is very important in the diagnosis of a haematoma. ${ }^{9}$ We would like to stress that imaging should be done to support a neurological examination, but not to replace it.

The treatment of spinal subdural haematoma with neurological deficit is timely surgery. A recent review of spinal subdural haematoma showed that only onethird of the cases recovered completely after laminectomy and clot evacuation. ${ }^{15}$ Failure to recover was related to long-standing compression of the spinal cord and/or cauda equina. ${ }^{15}$ We think that the patient reported here was fortunate to be diagnosed and treated before any permanent damage to the cauda equina and/or conus medullaris occurred.

\section{References}

1 Gormley JB. Treatment of postspinal headache. Anesthesiology 1960; $21: 565-6$.

2 Ozdil T, Powell WF. Post lumbar puncture headache: an effective method of prevention. Anesth Analg 1965; 44: 542-5.

3 DiGiovanni AJ, Dunbar BS. Epidural injections of autologous blood for postlumbar-puncture headache. Anesth Analg 1970; 49: 268-71.

4. Ostheimer GW, Palahniuk RJ, Shnider SM. Epidural blood patch for post-lumbar-puncture headache (Letter). Anesthesiology 1974; 41: 307-8.

5 Abouleish E, de la Vega S, Blendinger I, Tio T-O. Longterm follow-up of epidural blood patch. Anesth Analg 1975; 54: 459-63.

6 Shantha TR, McWhirter WR, Dunbar RW. Case history. Complications following epidural "blood patch" for postlumbar-puncture headache. Anesth Analg 1973; 52: 67-72.

7 Cornwall RD, Dolan WM. Radicular back pain following lumbar epidural blood patch. Anesthesiology 1975; 43: 692-3.

8 Walpole JB. Blood patch for spinal headache. A recurrence and a complication. Anaesthesia 1975; 30: 783-5.

9 Beards SC, Jackson A, Griffiths AG, Horsman EL. Magnetic resonance imaging of extradural blood patches: appearances from $30 \mathrm{~min}$ to $18 \mathrm{~h}$. Br J Anaesth 1993; 71; 182-8.

10 Reynolds F, Speedy HM. The subdural space: the third place to go astray. Anaesthesia 1990; 45: 120-3.

11 Reynolds AF Jr, Hameroff SR, Blitt CD, Roberts WL. Spinal subdural epiarachnoid hematoma: a complication of a novel epidural blood patch technique. Anesth Analg 1980; 59: 702-3.

12 Wood KM. The use of phenol as a neurolytic agent: a review. Pain 1978; 5: 205-29.

13 Greensite FS, Katz J. Spinal subdural hematoma associated with attempted epidural anesthesia and subsequent continous spinal anesthesia. Anesth Analg 1980; 59: 72-3.

14 Tekkok IH, Cataltepe O, Tahta K, Bertan V. Extradural haematoma after continuous extradural anaesthesia. $\mathrm{Br} \mathrm{J}$ Anaesth 1991; 67: 112-5.

15 Russell NA, Benoit BG. Spinal subdural hematoma. A review. Surg Neurol 1983; 20: 133-7. 